\title{
Synthesis and Characterization of a Tetraaza Macrocyclic Nickel(II) Complex Bearing Two Amidine Pendant Arms: Unprecedented Strong Metal-Pendant Arm Interaction
}

\author{
Shin-Geol Kang, ${ }^{*}$ Jae Keun Kweon, and Jong Hwa Jeong ${ }^{\dagger}$ \\ Department of Chemistry, Daegu University, Gyeongsan 712-714, Korea. *E-mail: sgkang@daegu.ac.kr \\ ${ }^{\dagger}$ Department of Chemistry, Kyungpook National University, Daegu 702-701, Korea \\ Received July 15, 2005
}

Key Words : Macrocyclic complex, Amidine groups, Functional pendant arms, Nickel(II) complex, X-ray structure

There has been continuing interest in the preparation of new polyaza macrocyclic compounds bearing various types of functional pendant arms, since chemical properties of such compounds are influenced by the nature of the functional groups. ${ }^{1-12}$

Some coordinated organic nitriles $(\mathrm{R}-\mathrm{CN})$ in transition metal complexes react with $\mathrm{H}_{2} \mathrm{O}$, $\mathrm{R}^{\prime} \mathrm{OH}$, or $\mathrm{R}^{\prime \prime}-\mathrm{NH}_{2}$ under relatively mild conditions to produce amides $\left(\mathrm{RCONH}_{2}\right)$, imidate esters $(\mathrm{R}-\mathrm{C}(=\mathrm{NH})-\mathrm{OR})$, or amidines $(\mathrm{R}-\mathrm{C}(=\mathrm{NH})$ NHR"). ${ }^{11-17}$ Recently, such reactions have been successfully applied to the preparation of functionalized polyaza macrocyclic compounds. ${ }^{3-7,11,12}$ For example, the trans-octahedral complexes $\left[\mathrm{NiL}^{4}\right]^{2+}$ and $\left[\mathrm{NiL}^{5}\right]^{2+}$ bearing two coordinated amide or imidate ester groups have been prepared by the reaction of $\left[\mathrm{NiL}^{2}\right]^{2+}$ with water or methanol. ${ }^{7}$ It has been revealed that, in the case of $\left[\mathrm{NiL}^{5}\right]^{2+}$, the axial $\mathrm{Ni}-\mathrm{N}$ (pendant imidate ester group) distance (2.100(3) $\AA$ ) is considerably shorter than the in-plane $\mathrm{Ni}-\mathrm{N}$ (tertiary amino group) distance $(2.118(3) \AA$ ) and is similar to the Ni-N (secondary amino group) distance $(2.097(3) \AA)^{7}{ }^{7}$ This trend is different from the observation that the axial $\mathrm{Ni}-\mathrm{X}(\mathrm{X}=\mathrm{N}$ or $\mathrm{O}$ atom of a functional pendant arm) distances of most di- $N$-functionalized macrocyclic complexes, such as $\left[\mathrm{NiL}^{4}\right]^{2+},\left[\mathrm{NiL}^{6}\right]^{2+}$, and $\left[\mathrm{NiL}^{7}\right]^{2+}$, are much longer than all of the in-plane Ni-N distances. ${ }^{7-10}$ It has been also reported that the imidate ester groups of $\left[\mathrm{NiL}^{5}\right]^{2+}$ are quite resistant to hydrolysis, unlike most coordinated imidate esters. ${ }^{7}$ This has been attributed to the strong Ni-N (pendant imidate ester group) interactions. However, the effects of strong axial $\mathrm{Ni}$-X (functional pendant arm) interactions on chemical properties of such macrocyclic complexes are not thoroughly investigated.
Therefore, we have been interested in the design and synthesis of various types of macrocyclic complexes with relatively short axial $\mathrm{Ni}-\mathrm{X}$ (functional pendant arm) bonds.

Herein, we report a new nickel(II) complex $\left[\mathrm{NiL}^{3}\right]\left(\mathrm{ClO}_{4}\right)_{2}$. $2 \mathrm{CH}_{3} \mathrm{CN}$ (1) bearing two pendant amidine groups $\left(-\mathrm{CH}_{2}-\right.$ $\left.\mathrm{C}(=\mathrm{NH})-\mathrm{NH}-\left(\mathrm{CH}_{2}\right)_{2} \mathrm{CH}_{3}\right)$. The complex was prepared by the reaction of $\left[\mathrm{NiL}^{2}\right]\left(\mathrm{ClO}_{4}\right)_{2}$ with $n$-propylamine. Interestingly, the Ni-N (pendant amidine group) distance of $\mathbf{1}$ is considerably shorter than the Ni-N (pendant imidate ester group) distance of $\left[\mathrm{NiL}^{5}\right]^{2+}$. Furthermore, the oxidation potential of $\mathbf{1}$ is extraordinarily lower than those of $\left[\mathrm{NiL}^{5}\right]^{2+}$ and other related trans-octahedral nickel(II) complexes. The effects of the pendant amidine groups upon the structure and chemical properties of $\mathbf{1}$ are described. The cobalt(III) complexes $\left[\mathrm{CoL}^{9}\right]^{3+}$ and $\left[\mathrm{CoL}^{10}\right]^{3+}$, in which the amidine group $(-\mathrm{C}(=\mathrm{NH})-\mathrm{NH}-)$ is incorporated into the macrocyclic framework, have been prepared. ${ }^{11,12}$ However, as far as we know, 14-membered tetraaza macrocyclic complexes bearing amidine pendant arms are not reported to date.

\section{Experimental Section}

Measurements. Elemental analyses and FAB mass spectra were performed at the Korea Basic Science Institute, Daegu, Korea. Infrared spectra were recorded using a Shimadzu IR440 spectrophotometer, electronic absorption spectra with an Analytikjena Specord 200 UV/Vis spectrophotometer, and conductance measurements with a Metrohm Herisau Conductometer E518. Magnetic moments were calculated from magnetic susceptibility data obtained at $20{ }^{\circ} \mathrm{C}$ using a Johnson Matthey MK-1 magnetic susceptibility balance.
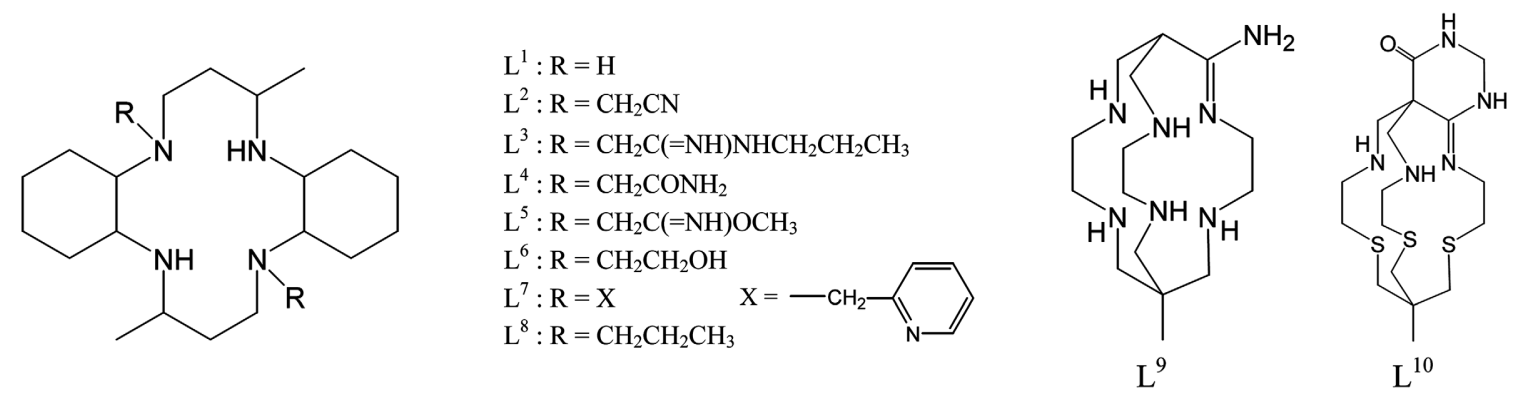
Cyclic voltammograms were recorded using a BAS-100 B/W auto cyclic volt/ampere meter. The working and counter electrodes were platinum, and the reference electrode was saturated calomel electrode (SCE). The electrochemical measurements were conducted in $0.1 M(n-\mathrm{Bu})_{4} \mathrm{NClO}_{4}$ acetonitrile solutions at $20^{\circ} \mathrm{C}$.

Preparation of $\left[\mathrm{NiL}^{3}\right]\left(\mathrm{ClO}_{4}\right)_{2} \cdot \mathbf{2} \mathrm{CH}_{3} \mathrm{CN}$ (1). Caution! Perchlorate salts of metal complexes with organic ligands are often explosive and should be handled with great caution. The complex $\left[\mathrm{NiL}^{2}\right]\left(\mathrm{ClO}_{4}\right)_{2}$ was prepared as described before. ${ }^{7}$ To a warm acetonitrile suspension (20 $\mathrm{mL})$ of $\left[\mathrm{NiL}^{2}\right]\left(\mathrm{ClO}_{4}\right)_{2}(1.0 \mathrm{~g})$ was added an excess of $n$ propylamine $(0.5 \mathrm{~mL})$. The mixture was stirred at room temperature for $10 \mathrm{~min}$. During this time the orange-red solid went to the solution, and then a purple solid was precipitated. The purple solid was filtered, washed with methanol, and dried in air. The product was recrystallized from hot acetonitrile-water $(1: 1)$ solution. Yield $\sim 80 \%$. Anal. Found: C, 46.55; H, 7.67; N, 15.88. Calc. for $\mathrm{C}_{34} \mathrm{H}_{66} \mathrm{~N}_{10} \mathrm{Cl}_{2} \mathrm{NiO}_{8}$ : C, 46.80; H, 7.62; N, 16.05\%. FAB Mass $(\mathrm{m} / \mathrm{z}): 689\left\{\left[\mathrm{M}-2 \mathrm{CH}_{3} \mathrm{CN}-\mathrm{ClO}_{4}\right]^{+}\right\}$and $589\{[\mathrm{M}-\mathrm{H}-$ $\left.\left.2 \mathrm{CH}_{3} \mathrm{CN}-2 \mathrm{ClO}_{4}\right]^{+}\right\}$. IR $\left(\mathrm{cm}^{-1}\right): 3340[v(\mathrm{~N}-\mathrm{H})], 3300[v(\mathrm{~N}-$ $\mathrm{H})], 3250[v(\mathrm{~N}-\mathrm{H})], 1630[v(\mathrm{C}=\mathrm{N})$ of $(-\mathrm{C}(=\mathrm{NH})-\mathrm{NH}-\mathrm{C}]$, and $1540(-\mathrm{C}(=\mathrm{NH})-\mathrm{NH}-\mathrm{C}) \cdot \mu_{\mathrm{eff}}=2.88 \mu_{\mathrm{B}}$. at $20{ }^{\circ} \mathrm{C}$.

Crystal structure analysis. Pale purple crystals of $\mathbf{1}$ suitable for X-ray study were grown from water-acetonitrile. A single crystal was selected for indexing and intensity data collection on CAD4 diffractometer. 4024 unique reflections from 4328 collected reflections were obtained and were corrected for Lorentz and polarization effects as well as absorption corrections with $3 \psi$ scans $(88.2 \%)$. The structures were determined by direct methods and refined by fullmatrix least-squares on $F^{2}$ with reflections above $2 \sigma$ level using SHLEXS-97 and SHLEXL-97. ${ }^{18}$ All non-hydrogen

Table 1. Crystal Data and Structure Refinement for $\mathbf{1}$

\begin{tabular}{|c|c|}
\hline Formula (formula weight) & $\mathrm{C}_{34} \mathrm{H}_{66} \mathrm{Cl}_{2} \mathrm{~N}_{10} \mathrm{NiO}_{8}(872.56)$ \\
\hline Crystal size $/ \mathrm{mm}$ & $0.45 \times 0.45 \times 0.50$ \\
\hline Temp $/{ }^{\circ} \mathrm{C}$ & $20(2)$ \\
\hline Crystal system, Space group & monoclinic, $\mathrm{P} 2{ }_{1} / \mathrm{n}$ \\
\hline$a / \AA$ & $9.2686(8)$ \\
\hline$b / \AA$ & $14.6007(9)$ \\
\hline$c / \AA$ & $16.6454(8)$ \\
\hline$\beta /^{\circ}$ & $105.537(6)$ \\
\hline $\mathrm{V} / \AA^{3}$ & $2170.3(3)$ \\
\hline $\mathrm{Z}$ & 4 \\
\hline$\rho($ calcd $) / \mathrm{g} \mathrm{cm}^{-3}$ & 1.335 \\
\hline$F_{000}$ & 932 \\
\hline$\mu / \mathrm{cm}^{-1}$ & 6.028 \\
\hline Theta range $/{ }^{\circ}$ & $1.89-25.47$ \\
\hline Index ranges & $-11 \leq h \leq 10,0 \leq k \leq 17,0 \leq l \leq 20$ \\
\hline Reflections collected / unique & $4328 / 4024[\mathrm{R}(\mathrm{int})=0.0161]$ \\
\hline Completeness to 2 theta $=25.97$ & 1.000 \\
\hline Data / restraints / parameters & $4024 / 0 / 245$ \\
\hline GOF on $\mathrm{F}^{2}$ & 1.125 \\
\hline Final $R$ indices $[\mathrm{I}>2$ sigma(I)] & $\mathrm{R}_{1}=0.060, \mathrm{wR}_{2}=0.195$ \\
\hline $\mathrm{R}$ indices (all data) & $\mathrm{R}_{1}=0.086, \mathrm{wR}_{2}=0.205$ \\
\hline Largest diff. Peak and hole $\left(\mathrm{e} \AA^{-3}\right)$ & 0.893 and -0.785 \\
\hline
\end{tabular}

(a)

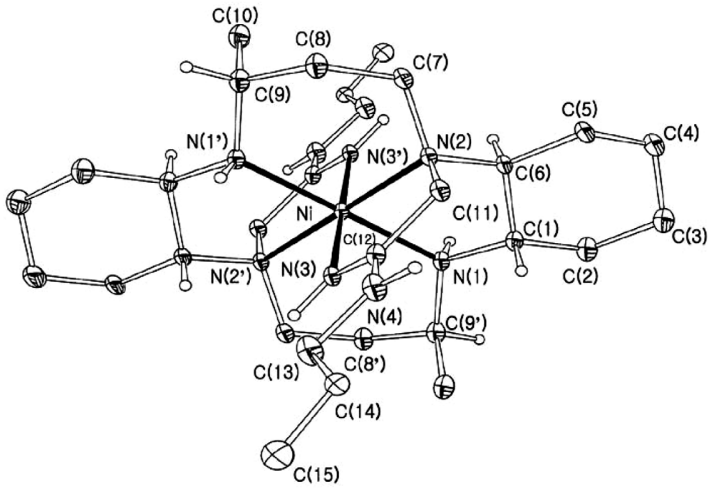

(b)

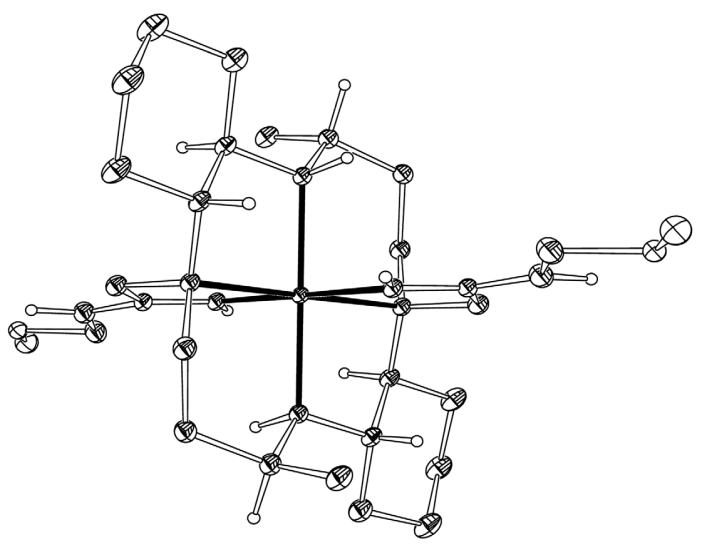

Figure 1. X-ray structure of $\left[\mathrm{NiL}^{3}\right]^{2+}$ in 1: (a) perspective view with the atomic numbering scheme; (b) side view.

atoms were refined anisotropically except C(14), C(15), and all $\mathrm{O}$ atoms at $\mathrm{ClO}_{4}$ which were distorted and then refined isotropically. All hydrogen atoms were calculated using riding models except $\mathrm{H}(1 \mathrm{~N}), \mathrm{H}(3 \mathrm{~N})$, and $\mathrm{H}(4 \mathrm{~N})$ which were fixed at located positions from differential Fourier map. The crystal and refinement data are listed in Table 1.

\section{Results and Discussion}

Crystal Structure. Figure 1 shows that the $\mathrm{N}-\mathrm{CH}_{2}-$ $\mathrm{C}(=\mathrm{NH})-\mathrm{NH}-\left(\mathrm{CH}_{2}\right)_{2} \mathrm{CH}_{3}$ pendant arms of $\mathbf{1}$ are coordinated to the metal ion through the nitrogen atoms of the $\mathrm{C}=\mathrm{NH}$ groups. The complex has distorted octahedral coordination geometry with an inversion center at the metal ion. The macrocyclic ligand has a trans-III type $N$-conformation. ${ }^{9,19,20}$ The cyclohexane rings and the six-membered chelate rings adopt chair conformations.

Selected bond distances and angles of the complex are listed in Table 2. One of the most remarkable structural features of the complex is that the axial Ni-N(3) (pendant arm) distance $(2.088(3) \AA$ ) is considerably shorter than the in-plane Ni-N(1) (2.115(3) $\AA$ ) and Ni-N(2) (2.123(3) $\AA$ ) distances. This trend is in sharp contrast to those reported for $\left[\mathrm{NiL}^{4}\right]\left(\mathrm{ClO}_{4}\right)_{2},\left[\mathrm{NiL}^{5}\right]\left(\mathrm{ClO}_{4}\right)_{2},\left[\mathrm{NiL}^{6}\right]\left(\mathrm{ClO}_{4}\right)_{2}$, and $\left[\mathrm{NiL}^{7}\right] \mathrm{Cl}_{2}$ (see Table 3). ${ }^{7-10}$ The Ni-N(3) distance is shorter than the axial Ni-N (imidate ester pendant arm) distance (2.100(3) $\AA$ ) of $\left[\mathrm{NiL}^{5}\right]\left(\mathrm{ClO}_{4}\right)_{2}{ }^{7}$ On the other hand, the in-plane Ni-N(1) 
Table 2. Selected Bond Distances $[\AA]$ and Angles $\left[{ }^{\circ}\right]$ for $\mathbf{1}$

\begin{tabular}{llll}
\hline $\mathrm{Ni}-\mathrm{N}(1)$ & $2.115(3)$ & $\mathrm{Ni}-\mathrm{N}(2)$ & $2.123(3)$ \\
$\mathrm{Ni}-\mathrm{N}(3)$ & $2.088(3)$ & $\mathrm{N}(1)-\mathrm{C}(1)$ & $1.489(5)$ \\
$\mathrm{N}(3)-\mathrm{C}(12)$ & $1.287(5)$ & $\mathrm{N}(4)-\mathrm{C}(12)$ & $1.332(5)$ \\
$\mathrm{N}(4)-\mathrm{C}(13)$ & $1.448(5)$ & $\mathrm{C}(1)-\mathrm{C}(2)$ & $1.530(6)$ \\
$\mathrm{C}(2)-\mathrm{C}(3)$ & $1.538(7)$ & $\mathrm{C}(3)-\mathrm{C}(4)$ & $1.486(8)$ \\
$\mathrm{C}(14)-\mathrm{C}(15)$ & $1.364(2)$ & & \\
$\mathrm{N}\left(1^{\prime}\right)-\mathrm{Ni}-\mathrm{N}(1)$ & $180.0(2)$ & $\mathrm{N}(3)-\mathrm{Ni}-\mathrm{N}\left(3^{\prime}\right)$ & $180.0(2)$ \\
$\mathrm{N}(1)-\mathrm{Ni}-\mathrm{N}(2)$ & $83.7(2)$ & $\mathrm{N}(1)-\mathrm{Ni}-\mathrm{N}\left(2^{\prime}\right)$ & $96.3(2)$ \\
$\mathrm{N}(1)-\mathrm{Ni}-\mathrm{N}(3)$ & $95.3(2)$ & $\mathrm{N}(3)-\mathrm{Ni}-\mathrm{N}\left(1^{\prime}\right)$ & $84.8(2)$ \\
$\mathrm{N}(2)-\mathrm{Ni}-\mathrm{N}(3)$ & $80.7(2)$ & $\mathrm{C}(12)-\mathrm{N}(3)-\mathrm{Ni}$ & $115.6(2)$ \\
$\mathrm{C}(11)-\mathrm{N}(2)-\mathrm{Ni}$ & $110.7(2)$ & $\mathrm{C}(12)-\mathrm{N}(4)-\mathrm{C}(13)$ & $123.9(4)$ \\
$\mathrm{N}(3)-\mathrm{C}(12)-\mathrm{C}(11)$ & $119.3(3)$ & $\mathrm{N}(3)-\mathrm{C}(12)-\mathrm{N}(4)$ & $126.3(4)$ \\
$\mathrm{N}(4)-\mathrm{C}(12)-\mathrm{C}(11)$ & $114.4(3)$ & $\mathrm{N}(4)-\mathrm{C}(13)-\mathrm{C}(14)$ & $116.7(6)$ \\
\hline
\end{tabular}

Symmetry transformations used to generate equivalent atoms: $-\mathrm{x},-\mathrm{y},-\mathrm{z}$

and Ni-N(2) distances are $c a .0 .01 \AA$ longer than the Ni$\mathrm{N}$ (secondary) and $\mathrm{Ni}-\mathrm{N}$ (tertiary) distances, respectively, of $\left[\mathrm{NiL}^{5}\right]\left(\mathrm{ClO}_{4}\right)_{2}{ }^{7}$ The $\mathrm{N}(3)-\mathrm{C}(12)$ bond distance $(1.287(5) \AA)$ is $c a .0 .03 \AA$ longer than the $\mathrm{N}=\mathrm{C}$ distance (1.258(5) $\AA$ ) of the imidate ester groups in $\left[\mathrm{NiL}^{5}\right]\left(\mathrm{ClO}_{4}\right)_{2}{ }^{7}$ It is also seen that the $\mathrm{N}(4)-\mathrm{C}(12)$ distance $(1.332(5) \AA)$ is considerably shorter than other N-C single bond distances $(\geq 1.448(5) \AA)$. The $\mathrm{N}(3)-\mathrm{C}(12)-\mathrm{N}(4)$ and $\mathrm{C}(12)-\mathrm{N}(4)-\mathrm{C}(13)$ angles are 126.3(4) and $123.9(4)^{\circ}$, respectively, indicating $\mathrm{sp}^{2}$-like hybridization of the $\mathrm{C}(12)$ and $\mathrm{N}(4)$ atoms. The $\mathrm{N}(2)-\mathrm{Ni}-\mathrm{N}(3)$ and $\mathrm{N}(1)-$ $\mathrm{Ni}-\mathrm{N}(3)$ angles are $90.7(2)$ and $95.3(2)^{\circ}$, respectively.

Above crystallographic observations strongly indicate that the shorter axial Ni-N(3) distance of $\mathbf{1}$, compared to that of $\left[\mathrm{NiL}^{5}\right]\left(\mathrm{ClO}_{4}\right)_{2}$, is connected to the delocalized electronic structure of the amidine groups (Eq. (1)); the lone pair of electrons on the uncoordinated nitrogen atom $(\mathrm{N}(4))$ is partially delocalized across the whole amidine group, and the donor nitrogen atom acts as a stronger Lewis base. ${ }^{11}$

Table 3. Selected bond distances and redox potentials of various trans-octahedral nickel(II) complexes

\begin{tabular}{lllcl}
\hline \multirow{2}{*}{ Complex } & \multicolumn{2}{c}{$\mathrm{Ni}-\mathrm{N}$ or Ni-O $(\AA)$} & \multicolumn{2}{c}{ Potential $(\mathrm{V} v s . \mathrm{SCE})^{a}$} \\
\cline { 2 - 5 } & \multicolumn{1}{c}{ In-plane } & Axial & $\mathrm{Ni}(\mathrm{II}) / \mathrm{Ni}(\mathrm{III}) \mathrm{Ni}(\mathrm{II}) / \mathrm{Ni}(\mathrm{I})$ \\
\hline$\left[\mathrm{NiL}^{1}\right]\left(\mathrm{ClO}_{4}\right)_{2}{ }^{b}$ & $1.952(4)^{c}$ & & +1.08 & -1.28 \\
& $2.115(3)$ & $2.088(3)$ & +0.78 & $-1.68(\mathrm{i})^{d}$ \\
& $2.123(3)$ & & & \\
{$\left[\mathrm{NiL}^{4}\right]\left(\mathrm{ClO}_{4}\right)_{2}{ }^{e}$} & $1.903(4)$ & $2.302(3)$ & +1.09 & \\
& $2.204(3)$ & & & \\
$\left.\mathrm{NiiL}^{5}\right]\left(\mathrm{ClO}_{4}\right)_{2}$ & $2.097(3)^{f}$ & $2.100(3)^{f}$ & +1.02 & \\
& $2.118(3))^{f}$ & & & \\
$\left.\mathrm{NiL}^{6}\right]\left(\mathrm{ClO}_{4}\right)_{2}{ }^{g}$ & $2.085(4)$ & $2.149(4)$ & +1.14 & $-1.13(\mathrm{i})$ \\
& $2.099(4)$ & & & \\
{$\left[\mathrm{NiL}^{7}\right] \mathrm{Cl}_{2}{ }^{h}$} & $2.095(5)$ & $2.255(4)$ & +1.15 & $-1.15(\mathrm{i})$ \\
& $2.109(4)$ & & & \\
{$\left[\mathrm{NiL}^{8}\right]\left(\mathrm{ClO}_{4}\right)_{2}{ }^{b}$} & $1.981(2)^{c}$ & & $+1.60(\mathrm{i})$ & -1.04 \\
\hline
\end{tabular}

${ }^{a}$ Measured in $0.1 \mathrm{M}(n-\mathrm{Bu})_{4} \mathrm{NClO}_{4}$ acetonitrile solution. ${ }^{b}$ Ref. 20 . ${ }^{c}$ Average in-plane Ni-N bond distance. ${ }^{{ }} \mathrm{i}=$ irreversible. ${ }^{\circ}$ Refs. 7 and 8. ${ }^{{ }^{c}}$ Ref. 7. ${ }^{g}$ Ref. 9. ${ }^{h}$ Ref. 10.
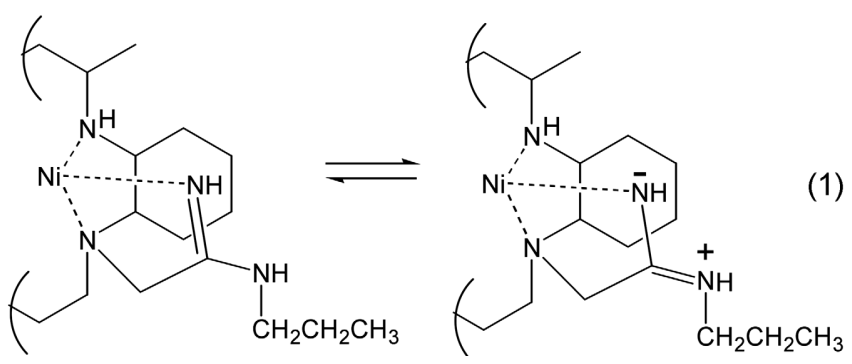

Spectra and Properties. As described above, 1 was prepared in high yield by the reaction of $\left[\mathrm{NiL}^{2}\right]\left(\mathrm{ClO}_{4}\right)_{2}$ with an excess of $n$-propylamine in acetonitrile at room temperature. The complex is soluble in polar solvents such as water, acetonitrile, and nitromethane. The FAB mass spectrum of $\mathbf{1}$ shows two groups of peaks at m/z $689\left\{\left[\mathrm{M}-2 \mathrm{CH}_{3} \mathrm{CN}-\right.\right.$ $\left.\left.\mathrm{ClO}_{4}\right]^{+}\right\}$and $589\left\{\left[\mathrm{M}-\mathrm{H}-2 \mathrm{CH}_{3} \mathrm{CN}-2 \mathrm{ClO}_{4}\right]^{+}\right\}$. In the infrared spectrum, three strong peaks corresponding to $v(\mathrm{~N}-\mathrm{H})$ of the coordinated secondary amino groups and the amidine groups $\left(-\mathrm{C}(=\mathrm{NH})-\mathrm{NH}-\mathrm{CH}_{2}-\right)$ were observed at 3250,3300 , and $3340 \mathrm{~cm}^{-1}$. The spectrum also shows $v(\mathrm{C}=\mathrm{N})$ and $v(\mathrm{C}-$ $\mathrm{N})$ of the amidine groups at 1630 and $1540 \mathrm{~cm}^{-1}$, respectively. The value of magnetic moment $\left(2.88 \mu_{\mathrm{B}}\right.$ at room temperature) of $\mathbf{1}$ is consistent with a $\mathrm{d}^{8}$ electronic configuration in octahedral coordination geometry. The electronic absorption spectrum of the complex measured in water shows maximum absorptions at $510\left(\varepsilon=8.0 \mathrm{M}^{-1} \mathrm{~cm}^{-1}\right)$ and $800 \mathrm{~nm}\left(\varepsilon=7.5 \mathrm{M}^{-1} \mathrm{~cm}^{-1}\right)$. The spectrum is comparable with those of $\left[\mathrm{NiL}^{5}\right]^{2+}$ and other related trans-octahedral nickel(II) complexes. ${ }^{7-10}$

In order to investigate the effects of the strong axial Ni-N interactions on the redox properties of $\mathbf{1}$, its oxidation and reduction potentials were measured by cyclic voltammetry. The oxidation potential of $\left[\mathrm{NiL}^{5}\right]\left(\mathrm{ClO}_{4}\right)_{2}$ was also measured for comparison. Cyclic voltammograms of $\mathbf{1}$ showed oneelectron oxidation and reduction peaks corresponding to $\mathrm{Ni}(\mathrm{II}) / \mathrm{Ni}(\mathrm{III})$ and $\mathrm{Ni}(\mathrm{II}) / \mathrm{Ni}(\mathrm{I})$ processes, respectively. Table 3 shows that the oxidation and/or reduction potentials of $\mathbf{1}$ and $\left[\mathrm{NiL}^{5}\right]\left(\mathrm{ClO}_{4}\right)_{2}$ bearing two coordinated functional pendant arms are much more negative than those of $\left[\mathrm{NiL}^{8}\right]\left(\mathrm{ClO}_{4}\right)_{2}$ bearing two $N$-alkyl pendant arms, as usual. ${ }^{8-10,20}$ The oxidation potential $(+1.02 \mathrm{~V} v s$. SCE $)$ of $\left[\mathrm{NiL}^{5}\right]\left(\mathrm{ClO}_{4}\right)_{2}$ is comparable with those of the transoctahedral nickel(II) complexes of $\mathrm{L}^{4}, \mathrm{~L}^{6}$, and $\mathrm{L}^{7}(+1.09$ $+1.15 \mathrm{~V}$ vs. SCE) (Table 3). ${ }^{7-10}$ However, interestingly, the oxidation and reduction potentials $(+0.78$ and $-1.68 \mathrm{~V} v s$. SCE) of $\mathbf{1}$ are considerably less positive and more negative, respectively, than those of the nickel(II) complexes of $\mathrm{L}^{4}-\mathrm{L}^{7}$ and other related 14-membered tetraaza macrocycles bearing two functional pendant arms. ${ }^{7-10,15}$ To our knowledge, 1 is a rarely prepared di- $N$-functionalized 14 -memberd tetraaza macrocyclic nickel(II) complex that exhibits the oxidation potential at $+0.80 \mathrm{~V} v s$. SCE. The relatively easy oxidation of 1 must be resulted from the high electron density on the metal ion caused by the strong axial $\mathrm{Ni}-\mathrm{N}$ (amidine group) interactions.

It has been well known that most uncoordinated organic 
Table 4. Electronic Absorption Spectral Data for the Nckel(II) Complexes

\begin{tabular}{ll}
\hline \multicolumn{1}{c}{ Complex } & $\lambda \max , \mathrm{nm}\left(\varepsilon, \mathrm{M}^{-1} \mathrm{~cm}^{-1}\right)^{a}$ \\
\hline $\mathbf{1}^{b}$ & $510(8) \quad 800(7.5)$ \\
{$\left[\mathrm{NiL}^{4}\right]\left(\mathrm{ClO}_{4}\right)_{2}{ }^{b}$} & $525(6.9)$ \\
{$\left[\mathrm{NiL}^{5}\right]\left(\mathrm{ClO}_{4}\right)_{2}{ }^{c, d}$} & $513(12) 800(5.5)$ \\
{$\left[\mathrm{NiL}^{6}\right]\left(\mathrm{ClO}_{4}\right)_{2}{ }^{f}$} & $516(7.2)$ \\
{$\left[\mathrm{NiL}^{7}\right]\left(\mathrm{ClO}_{4}\right)_{2}{ }^{f}$} & $530(6.0)$ \\
& $527(6.4)^{g}$ \\
{$\left[\mathrm{NiL}^{8}\right]\left(\mathrm{ClO}_{4}\right)_{2}{ }^{h}$} & $486(103)$
\end{tabular}

${ }^{a}$ Measured in water at room temperature unless otherwise specified. ${ }^{b}$ The band around $320 \mathrm{~nm}$ is obscured by intense charge transfer band. ${ }^{c}$ Refs. 7 and 8. ${ }^{d}$ Measured in DMSO. ${ }^{e}$ Ref. 9. ${ }^{\circ}$ Ref. $10 .{ }^{g}$ Measured in acetonitrile. ${ }^{h}$ Ref. 20.

amidines are readily hydrolyzed in aqueous solutions. However, 1 was recrystallized from hot $\mathrm{HClO}_{4}(0.1 \mathrm{M})$ or $\mathrm{NaOH}(0.1 \mathrm{M})$ solution without any considerable hydrolysis. This clearly shows that the coordinated amidine pendant arms of the complex are resistant to hydrolysis in the aqueous solutions. All our attempts to isolate the free macrocyclic ligand $\mathrm{L}^{3}$ from the reaction of $\mathbf{1}$ with an excess of $\mathrm{NaCN}$ were unsuccessful; even after refluxing $(>6 \mathrm{~h})$ an aqueous solution of the mixture, the only complex isolated from the solution was the reactant $\mathbf{1}$. This result is quite different from the behaviors of most 14-membered tetraaza macrocyclic nickel(II) complexes $\left([\mathrm{NiL}]^{2+}\right.$ ) that readily react with $\mathrm{CN}^{-}$ion to produce $\left[\mathrm{Ni}(\mathrm{CN})_{4}\right]^{2-}$ and free macrocycle (L). ${ }^{5,7-10,20}$ One of the reasons for the exceptional inertness of $\left[\mathrm{NiL}^{3}\right]^{2+}$ against hydrolysis and decomposition may be the strong interactions between the central metal ion and the pendant amidine groups.

\section{Conclusion}

This work shows the preparation, crystal structure, and chemical properties of $\mathbf{1}$ bearing two pendant amidine groups that bind the metal ion strongly. The compound is a rarely prepared trans-octahedral macrocyclic nickel(II) complex, in which the axial Ni-N(functional pendant arm) distance is considerably shorter than all of the in-plane Ni-N (macrocyclic skeleton) distances. The oxidation and reduction potentials of $\mathbf{1}$ are remarkably less positive and more negative, respectively, than those of $\left[\mathrm{NiL}^{5}\right]\left(\mathrm{ClO}_{4}\right)_{2}$ or other related nickel(II) complexes. Furthermore, the complex is quite resistant to hydrolysis and is unusually inert against ligand substitution. Such chemical properties of $\mathbf{1}$ can be attributed to the relatively strong axial $\mathrm{Ni}-\mathrm{N}$ interactions.

Supplementary material. Crystallographic data of $\mathbf{1}$ are available from the Cambridge Structural Database (CCDC 259503). Copies of the data can be obtained free of charge, on application to CCDC, 12 Union Road, Cambridge CB2 IEZ, UK (http://www.ccdc.cam.ac.uk, fax: +44-1223-336033, or e-mail: deposit@ccdc.cam.ac.uk).
Acknowledgements. This work was supported in part by the Research Grant of Daegu University.

\section{References}

1. (a) Costamagna, J.; Ferraudi, G.; Matsuhiro, B.; Vampus-Vallette, M.; Canales, J.; Villagran, M.; Vargas, J.; Aguirre, M. J. Coord. Chem. Rev. 2000, 196, 125; (b) Wainwright, K. P. Coord. Chem. Rev. 1997, 166, 35; (c) Ryu, S. Y.; Yoon, M.; Choy, J. H.; Hwang, S. H.; Frube, A.; Asahi, T.; Masuhara, H. Bull. Korean Chem. Soc. 2003, 24,446

2. (a) Tei, L.; Blake, A. J.; Bencini, A.; Voltancoli, B.; Wilson, C.; Schröder, M. Inorg. Chim. Acta 2002, 337, 59; (b) Aneetha, H.; Lai, Y.-H.; Lin, S.-C.; Panneerselvam, K.; Lu, T.-H.; Chung, C.-S. J. Chem. Soc., Dalton Trans. 1999, 2885 and references cited therein; (c) Kang, S.-G.; Kim, S.-J.; Jeong, J. H. Inorg. Chim. Acta 2002, 340, 187; (d) Kang, S.-G..; Kim, S.-J. Bull. Korean Chem. Soc. 2003, 24, 1 .

3. Tei, L.; Blake, A. J.; Lippolis, V.; Wilson, C.; Schröder, M. Dalton Trans. 2003, 304.

4. Comparone, A.; Kaden, T. A. Helv. Chim. Acta 1998, 81, 1765.

5. Kaden, T. A. Chimica 2000, 54, 574.

6. (a) Wainwright, K. P. J. Chem. Soc., Dalton Trans. 1980, 2117; (b) Freeman, G. M.; Barefield, E. K.; Derveer, D. G. V. Inorg. Chem. 1984, 23, 3092.

7. Kang, S.-G.; Song, J.; Jeong, J. H. Bull. Korean Chem. Soc. 2002 , 23, 824 .

8. Choi, K.-Y.; Lee, H.-H.; Park, B.-B.; Kim, J. H.; Kim, M.-W.; Ryu, J.-W.; Suh, M.; Suh, I.-H. Polyhedron 2001, 20, 2002.

9. Kang, S.-G.; Kim, M. S.; Choi, J.-S.; Whang, D.; Kim, K. J. Chem. Soc., Dalton Trans. 1995, 363.

10. (a) Kang, S.-G.; Kim, S.-J.; Jeong, J. H. Polyhedron 1998, 17, 3227; (b) Choi, K.-Y.; Chun, K.-M.; Suh, I.-H. Polyhedron 1999, $18,2811$.

11. Angus, P. M.; Elliott, A. J.; Sargeson, A. M.; Willis, A. C. J. Chem. Soc., Dalton Trans. 2000, 2933.

12. Angus, P. M.; Sargeson, A. M.; Wills, A. C. Chem. Commun. 1999, 1975.

13. (a) Wagner, G. Inorg. Chim. Acta 2004, 357, 1320; (b) Garnovskii, D. A.; Kukushkin, V. Y.; Haukka, M.; Wagner, G.; Pombeiro, A. J. L. J. Chem. Soc., Dalton Trans. 2001, 560; (c) Kopylovich, M. N.; Kukushkin, V. Y.; Haukka, M.; Frausto da Silva, J. J. R.; Pombeiro, A. J. L. Inorg. Chem. 2002, 41, 4798.

14. (a) Kopylovich, M. N.; Pombeiro, A. J. L.; Fisher, A.; Kloo, L.; Kukushkin, V. Y. Inorg. Chem. 2003, 42, 7239; (b) Wang, L.-J.; Qu, Z.-R.; Zhao, H.; Wang, X.-S.; Xiong, R.-G.; Xue, Z.-L. Inorg. Chem. 2003, 42, 3969; (c) Yu, Z.; Wang, X.; Feng, Y.; Zhong, X. Inorg. Chem. Commun. 2004, 7, 492; (d) Hashimoto, T.; Hara, S.; Shiraishi, Y.; Natarajan, K.; Shimizu, K. Chem. Lett. 2003, 32, 874 .

15. Michelin, R. A.; Mozzon, M.; Bertani, R. Coord. Chem. Rev. 1996, 147, 299 and references cited therein.

16. (a) BoKach, N. A.; Kukushkin, V. Y.; Haukka, M.; Frausto da Silva, J. J. R.; Pombeiro, A. J. L. Inorg. Chem. 2003, 42, 3602; (b) Makarycheva-Mikhailova, A. V.; Kukushkin, V. Y.; Nazarov, A. A.; Garnovskii, D. A.; Pombeilo, A. J. L.; Haukka, M.; Keppler, B. K.; Galanski, M. Inorg. Chem. 2003, 42, 2805.

17. Murahashi, S.-I.; Naota, T. Bull. Chem. Soc. Jpn. 1996, 69, 1805.

18. (a) Sheldrick, G. M. SHELXS-97, Program for the Solution of Crystal Structure; University of Göttingen: Göttingen, Germany, 1990; (b) Sheldrick, G. M. SHELXL-97, Program for Crystal Structure Refinement; University of Göttingen: Göttingen, Germany, 1997.

19. Pierce, D. T.; Hatfield, T. L.; Billo, E. J.; Ping, Y. Inorg. Chem. 1997, 36, 2950

20. Kang, S.-G.; Kim, M.-S.; Whang, D.; Kim, K. Inorg. Chim. Acta 1998, 279, 238. 